\title{
THE ECONOMIC PRIORITIES OF THE BULGARIAN GOVERNMENTS IN THEIR PROGRAMMES OF ACTION (2001-2013)
}

\author{
M. Kasnakova \\ Department of Political Science, Faculty of Philosophy, "St. Kliment Ohridski" University of Sofia, \\ Sofia, Bulgaria
}

\begin{abstract}
The report presents the main economic priorities in the programmes of action of three successive Bulgarian governments in the period 2001 - 2013 (the cabinet of Simeon Sakskoburggotski, the cabinet of Sergey Stanishev and the first cabinet of Boyko Borisov). It uses the methodology of diachroniccomparative analysis to display key economic priorities and specific ones in relevant government programmes. The goal of this research is to evaluate the economic role of government in the formulation of national vision and strategy for prosperity. Government's programme of action is an essential document for the future intentions of the executive branch in a country with a democratic parliamentary form as Bulgaria. The report is based on the theoretical interpretation of the economic role of government and on the critical reading of the programmes of action of the Bulgarian governments in the section Economics and Management. In conclusion, the author note a lack of strictly ideological and political approach of the governments in the formulation of the main goals of economic development. Duplication of key government priorities and goals in the economic sphere leads the researcher to concluded that there are common principles and non-partisan nature of the initiatives for stable economic growth and prosperity of private business.
\end{abstract}

Key words: economic, priorities, government, programme, business

\section{INTRODUCTION}

Researchers Steven Peck and Robert Gibson note on the role of national governments in the economic sphere: "governments have a key role in the transition to an efficient, equitable and ecologically oriented economy. Governments, acting on strong position to set the political agenda, can create prerequisites for the development of their industries and citizens" (1). In the 90s of the 20th century governments move towards deregulation, cuts and reducing government deficits and some analysts describe this process as "reinventing government". Other authors, such as Muldoon and Nadarajah, marked "decline or withdrawal of government from traditional leading role to define and promote economic and social policy goals" and the transformation of governments in the only regulator in the national economy (2). According to David VJ Bell (3), director of the Center for the implementation of sustainable development to York University, the role of business is to generate wealth by providing products and services in a healthy economy, while the government's role is to guide the public to the goals expressed in public policy (i.e. the process of setting goals).
A number of authors agree that the government should develop a vision and strategy for sustainable economic growth. The vision and goal setting requires the ability to think and plan for the future, not only to master social and economic foresight. Governments at all levels and in all regions of the world are beginning to realize the importance of addressing the challenges for sound economic development. Each state with her national programmes can't be island of stability in a sea of instability. In this sense, the global context must be reflected in the agenda of domestic politics. The government's programme of action is an essential document for the future intentions of the government as the supreme executive authority in a country with a democratic parliamentary form of government. This programme, together with the national development plans, the laws on the state budget and the annual budgetary frameworks are the core of process of strategic planning in the public sector. The government's programme, adopted by the National Assembly (NA), is built on the basis of reasonable priorities that match national interests and public expectations for development and 
KASNAKOVA M.

prosperity of Bulgaria. The government's programme of action of Bulgarian government reveals the correlation with the trends in the EU common market and in the global market which dictate the need for accelerated and sustained economic growth, identified as: knowledge economy and innovation, development of competitive enterprises, increasing investment and exports and creating a favorable business environment.

\section{THE ECONOMIC PRIORITIES OF THE BULGARIAN GOVERNMENTS IN THEIR PROGRAMMES OF ACTION (2001-2013)}

The government's programme of action is developed in the first months in office and reflects the government's strategic vision for the goals, measures and activities of governance at a particular time. The successful implementation of the programmes means that the results of governance meet the set goals within a specified period (four years).

In the government's programme of action of 85th Government of the Republic of Bulgaria (the cabinet of Simeon Sakskoburggotski), supported by the Parliamentary Group of National Movement Simeon II (NMSS) and the Parliamentary Group of Movement for Rights and Freedoms (MRF) in the first place among the priorities is stipulated: creating a stable macroeconomic framework (4). This section outlines the key economic priorities for the prosperity of society:

$>$ Achieve high and sustainable average annual economic growth of $5-7 \%$ for the period 2002-2005 as a condition for a new quality of life and raising living standards;

$>$ Employment creation and increasing of incomes with a focus on reducing unemployment;

$>$ Investment policy for attracting substantial foreign investment from 1-1.2 billion dollars on average for the period 2002-2005. There is a commitment to create a favorable environment for Bulgarian and foreign investment and balanced development of small, medium and large businesses. The basis for this should be established the clear rules and principles of the market economy;

$>$ Improve the trade balance and current account balance and aggressive policy to stimulate exports and also Bulgaria to become a major exporter of products with high added value. In parallel, to restrict the trade deficit and the current account deficit, the government intends to increase the share of exports in GDP to improve the balance of payments and to strengthen macroeconomic stability. The foreign policy and the role of bilateral, regional and multilateral initiatives have main importance;

$>$ Fiscal policy under the currency board is assumed to be the main instrument of economic policy. The measures of a strict compliance with financial and budgetary discipline will be part of the policy of reducing the budget deficit and reach a zero budget deficit in 2005 . The controlling Inflation will become through the instruments of fiscal policy and this process will be part of the strategic priorities of the Government;

$>$ Monetary policy should ensure the preservation of macroeconomic stability by maintaining a policy of fixed exchange rate of the lev to the euro to Bulgaria joining the European Monetary Union.

In the government's programme of action of 86th Government of the Republic of Bulgaria (the cabinet of Sergey Stanishev), supported by the parliamentary group of Coalition for Bulgaria, parliamentary group of the National Movement for Stability and Progress (renamed NMSP) and the Parliamentary Group of Movement for Rights and Freedoms, the main economic priority is displayed still in title "Programme of the Government of European integration, economic growth and social responsibility" (5). The economic section contains the following key priorities:

$>$ Economic development towards catching up with the European Union, income growth and convergence of quality of life. In this aspect, increasing productivity and competitiveness of the Bulgarian economy - an active policy of rapprochement with the EU on key parameters set out in the Strategy for growth and jobs in the EU. The priorities include: establishing the 240,000 jobs and continuous improvement of the employment rate; reduce unemployment below 10\%; creating more opportunities for disadvantaged people, consistent care for Bulgarian children and higher pensions for Bulgarian pensioners;

$>$ Government efforts to maintain sustainable economic growth, stimulating the private initiative and continuing the processes of privatization, concessions, development of public-private partnership. This priority include: creating a stable and predictable macroeconomic environment; immediate entry into ERM II after accession to the EU; effective spending of public resources and greater freedom for private initiative; less debt 
burden for future generations; better business conditions and transparent, secure and modernized capital market;

$>$ Create conditions for high and sustainable economic growth of $6-8 \%$ per year, and development of market economy of competition. Continuing the processes of privatization, concessions, development of public-private partnership, stimulation of competition and liberalization while preserving the public interest;

$>$ Modernization of the state, development of the knowledge economy, skilling of the labor force according to the Strategy for growth and jobs in the EU. This implies management with care for every Bulgarian citizen through a modern administration and investment made in new technologies and industries;

$>$ Overcoming regional disparities, as well as dynamic development of the regions. This priority include: enhancement of the road and rail network; start of construction of Danube Bridge 2; active work on construction of highways; improving access to the settlements in remote areas with the budget resources and with the support of European funds; creating a competitive agriculture and forestry; more revenue for municipalities; support for the creation of technology parks and business incubators, as well as strengthening the capacity of public administration at central, regional and local level.

The Programme of 87th Government of European Development of Bulgaria (the first cabinet of Boyko Borisov) is initiated by the ruling majority in the face of a political party Citizens for European Development of Bulgaria (GERB) (6). In the section of the first priority "Improving the incomes of Bulgarian citizens, growth and modernization of the Bulgarian economy" are spelled out specific goals:

> Maintaining macroeconomic stability (maintaining a balanced budget, improving the quality of public finances, effective management of public debt, a transparent and secure financial market, increase the efficiency and effectiveness of the activities of the revenue administration, efficient management of public state property, continuing fiscal decentralization, as well as full membership in the European and international financial institutions);

$>$ Economic growth; attracting investments and development of Bulgarian business in general; increase in investment activity; proactive export policy and selective support investment in promising and export-oriented industries; improving the business environment; implementation of the commitments to the EU related to the effective functioning of Internal Market and prevent violations of the rules for its functioning; increasing the competitiveness of the Bulgarian economy through the Operational Program "Development of the Competitiveness of the Bulgarian Economy"; providing traceable and internationally recognized measurements to improve the quality and competitiveness of Bulgarian products and services; increase income Bulgarian citizens, maintaining and gradually raising the living standards of Bulgarian citizens in line with European principles and standards, and promoting the creation of employment);

$>$ Consumer Protection (effective enforcement of consumer protection and a high level of protection of their economic interests);

$>$ Energy Development (improving energy efficiency, building a competitive energy market as a way to achieve the priorities of competitiveness, energy security and sustainable development, security of energy supply for the Bulgarian industry and population, increasing the share of RES in gross final energy consumption, improve the investment environment in the field of prospecting, exploration and mining activities);

$>$ Sustainable tourism development (development of the legislative framework for the development of tourism and increasing the share of revenues from tourism in the national economy);

$>$ Development of agriculture as the foundation of economic development: conversion of agriculture and fisheries in attractive business and providing high living standards for employed in this sphere by stabilizing and increasing income from their activities; creation of a European vision of the administration in the sector "Agriculture" with main goal providing quality administrative services; improving agricultural production by improving the link "education Agricultural Advisory - Research"; increasing the competitiveness of Bulgarian agricultural products in terms of EU membership, implementing control about the food quality and safety; ensuring the production and supply of quality and safe agricultural products and 
foodstuffs; sustainable and competitive development of the forest sector in accordance with the principles of multifunctional forest management; improving the protection and support the adaptation of Bulgarian forests to climate change; creating conditions to support small and medium enterprises and development of income generating activities outside agriculture; creating conditions for the development of environmentally friendly forms of agriculture, aimed at protecting the environment and biodiversity);

$>$ Accelerated construction, maintenance and modernization of transport infrastructure (accelerate implementation of infrastructure projects in rail, road, water, air and combined transport; implementing of projects under the Operational Programme "Transport"; effective use of the mechanisms of publicprivate partnership and improving of the organization and management of transport, improvement of rail transport and improving the conditions at the aviation sector, the development of intermodal transport);

$>$ Introduction of new technologies (development of electronic communications and postal services; development of advanced broadband infrastructure, creation of modern ICT research, development of the knowledge economy and attracting investments, development of the information society and the development of e-government).

THE TOP PRIORITY FOR ALL: ACCELERATED AND SUSTAINED ECONOMIC GROWTH OF BULGARIAN ECONOMY

The detailed content analysis of the economic part in the programmes of three successive governments in Bulgaria, revealed as a common top priority achieving accelerated and sustained economic growth of the Bulgarian economy. In a period of high economic uncertainty is particularly important for governments to seek solutions to their countries adapt to the changing environment. In Bulgaria, the private sector is the main generator of vacancies and sustainable employment in the real economy. Economic growth depends largely on the available favorable conditions for doing private business. Therefore, the state (the government) should provide sufficient protection of private property, limited administrative procedures, reasonably regulate private relationships, low corruption and so on. The state must fulfill its main functions - to provide order, security and justice.

In the government programmes of the three cabinets in a period of 12 years clearly dominates a common fundamental priority accelerated and sustained economic growth of the Bulgarian economy into a competitive market. Common priority to these programmes of action is: a political commitment to structural reforms, maintaining low budget deficit and external debt, overcoming economic backwardness through investments in less developed regions, reducing unemployment, income growth and investment, support for Bulgarian exports, development of Bulgarian business and encouraging investment in modern and innovative industries, low share of reallocating funds from state support for small and medium businesses, and so on. These priorities largely correspond to the priorities of the Europe 2020 strategy: smart growth (developing an economy based on knowledge and innovation), sustainable growth (promoting a more resource efficient, greener and more competitive economy) and inclusive growth (stimulating the economy with high levels of employment, ensuring economic, social and territorial cohesion). The author has examined in detail the concrete goals and measures within economic priorities in order to identify the specific differences in the government programmes. In the Table $\mathbf{1}$ are derived concrete examples from the programmes of action:

Table 1. Specific goals and objectives for the implementation of the economic priorities of three successive Bulgarian governments (2001-2013)

\begin{tabular}{|c|c|c|c|}
\hline Key priority sectors & $\begin{array}{l}\text { the cabinet of Simeon } \\
\text { Sakskoburggotski }\end{array}$ & $\begin{array}{l}\text { the cabinet of Sergey } \\
\text { Stanishev }\end{array}$ & $\begin{array}{l}\text { the first cabinet of } \\
\text { Boyko Borisov }\end{array}$ \\
\hline Industry and Trade & $\begin{array}{l}\text { setting up a unit for } \\
\text { sectoral economic } \\
\text { analyzes; sector tourism } \\
\text { to be a leading one; } \\
\text { decentralization and } \\
\text { transfer of public finance } \\
\text { to industry organizations }\end{array}$ & $\begin{array}{lr}\text { optimization of license, } \\
\text { permit and registration } \\
\text { regimes; developing a } \\
\text { National } \\
\text { Strategy; } & \text { Export } \\
\text { cooperation } & \text { with the } \\
\text { OECD; } & \text { conducting }\end{array}$ & $\begin{array}{l}\text { legal powers to } \\
\text { municipalities to priority } \\
\text { regional projects; } \\
\text { Privatization } \\
\text { "Bulgartabac Holding" } \\
\text { privatization strategy of } \\
\text { "VMZ" EAD and }\end{array}$ \\
\hline
\end{tabular}


KASNAKOVA M.

\begin{tabular}{|c|c|c|c|}
\hline & & $\begin{array}{l}\text { proactive investment } \\
\text { marketing } \\
\text { international level at }\end{array}$ & $\begin{array}{l}\text { completion of the } \\
\text { privatization; accelerated } \\
\text { recovery of VAT to } 40 \\
\text { days; social dialogue; } \\
\text { establishment and } \\
\text { improvement of national } \\
\text { standards }\end{array}$ \\
\hline $\begin{array}{l}\text { Communications and } \\
\text { high technology }\end{array}$ & $\begin{array}{l}\text { creating a legislative } \\
\text { framework; striving for } \\
\text { Internet education; } \\
\text { reliefs for import; } \\
\text { building e-government; } \\
\text { establishment of an } \\
\text { investment fund }\end{array}$ & $\begin{array}{l}\text { promoting SMEs with } \\
\text { high innovation capacity; } \\
\text { creating a single } \\
\text { infrastructure for high- } \\
\text { speed } \\
\text { communications; } \\
\text { restructuring of the } \\
\text { "Bulgarian Posts"; } \\
\text { increasing government } \\
\text { spending on science and } \\
\text { promoting corporate } \\
\text { investment in research } \\
\text { and development }\end{array}$ & $\begin{array}{l}\text { entrepreneurship } \\
\text { education at all } \\
\text { educational levels and } \\
\text { creating of the } \\
\text { "knowledge factory" - } \\
\text { Youth Technology } \\
\text { Platform; a transition } \\
\text { from terrestrial analogue } \\
\text { to digital radio and } \\
\text { television broadcasting; } \\
\text { coordination of the } \\
\text { National Strategy for } \\
\text { development } \\
\text { broadband; construction } \\
\text { and development of e- } \\
\text { government }\end{array}$ \\
\hline Energy & 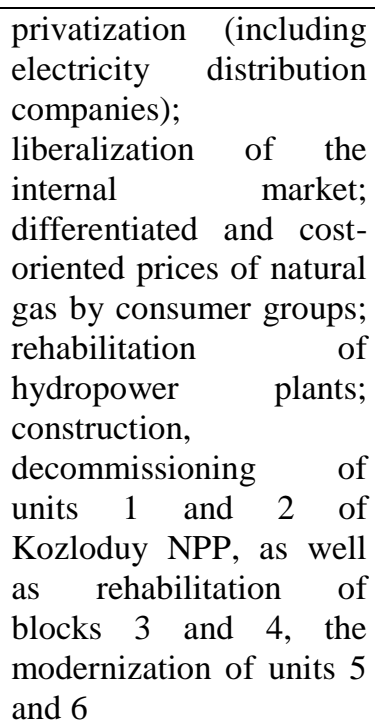 & $\begin{array}{l}\text { a greater proportion of } \\
\text { clean } \\
\text { (hydropower)and } \\
\text { implementing a system } \\
\text { of green certificates' } \\
\text { trade; introduction of } \\
\text { household gasification; } \\
\text { privatization of TPP } \\
\text { "Varna" and "Bobov } \\
\text { dol", Heating System } \\
\text { "Rousse" r and } \\
\text { restructuring of NEK } \\
\text { EAD and "Bulgargaz" } \\
\text { EAD }\end{array}$ & $\begin{array}{l}\text { limiting the dependence } \\
\text { on energy imports } \\
\text { through energy saving } \\
\text { and promoting the use of } \\
\text { local resources } \\
\text { (especially renewable } \\
\text { energy); participation of } \\
\text { the Bulgarian energy } \\
\text { installations in the EU } \\
\text { ETS allowances for } \\
\text { greenhouse gases; } \\
\text { adoption of the Energy } \\
\text { Strategy 2020; reducing } \\
\text { by } 20 \% \text { energy intensity } \\
\text { of GDP by } 2013\end{array}$ \\
\hline Tourism & $\begin{array}{l}\text { development of } \\
\text { infrastructure; } \\
\text { liberalization of the } \\
\text { regime of registration; } \\
\text { preparation of a law on } \\
\text { tourism; creating tourism } \\
\text { statistics }\end{array}$ & $\begin{array}{l}\text { adoption of a Law on the } \\
\text { Black Sea coast }\end{array}$ & $\begin{array}{l}\text { building institutional and } \\
\text { legislative framework for } \\
\text { the management of } \\
\text { tourism; development of } \\
\text { tourism that is related to } \\
\text { cultural heritage; } \\
\text { specialized tourism } \\
\text { (cultural tourism, spa and } \\
\text { wellness tourism, } \\
\text { tourism on the Danube); } \\
\text { budget resources for } \\
\text { tourist advertising }\end{array}$ \\
\hline $\begin{array}{l}\text { Agricultural and } \\
\text { Forestry }\end{array}$ & $\begin{array}{l}\text { completion of the } \\
\text { payment of benefits; } \\
\text { providing land to } \\
\text { landless; consolidation of } \\
\text { agricultural land; } \\
\text { information system in } \\
\text { this sector; conducting of } \\
\text { a stimulating credit } \\
\text { policy; government } \\
\text { regulation in the tobacco } \\
\text { production }\end{array}$ & $\begin{array}{l}\text { development of a } \\
\text { National Strategic Plan } \\
\text { and Program for rural } \\
\text { development for 2007- } \\
2013 \text {.; construction of a } \\
\text { single coordinating body } \\
\text { for animal health and } \\
\text { phyto-sanitary control of } \\
\text { the internal market; } \\
\text { adoption of a Property } \\
\text { Law }\end{array}$ & $\begin{array}{l}\text { implementation of the } \\
\text { Single Payment Scheme } \\
\text { (or Single Farm } \\
\text { Payment, SPS) for direct } \\
\text { subsidy payments to } \\
\text { landowners; updating of } \\
\text { the digital orthophoto } \\
\text { map (TSOFK); } \\
\text { accreditation of the } \\
\text { identification system for } \\
\text { farm animals and } \\
\text { establishing a payment of } \\
\text { subsidies per animal; }\end{array}$ \\
\hline
\end{tabular}


KASNAKOVA M.

\begin{tabular}{|c|c|c|c|}
\hline & & & $\begin{array}{l}\text { amending legislation in } \\
\text { the wine sector; } \\
\text { establishment of the } \\
\text { National Guarantee } \\
\text { Fund, through which to } \\
\text { ensure projects under the } \\
\text { Programme for Rural } \\
\text { Development; } \\
\text { improvement of the link } \\
\text { "research - Agricultural } \\
\text { Advisory - agricultural } \\
\text { business"; development } \\
\text { of an organic farming }\end{array}$ \\
\hline Transport & $\begin{array}{l}\text { liberalization (including } \\
\text { communications); } \\
\text { legislative changes; } \\
\text { reconstruction of the } \\
\text { railroad bridge Vidin- } \\
\text { Calafat, reconstruction } \\
\text { port of Burgas, Varna, } \\
\text { Lom and establishment a } \\
\text { new passenger terminal } \\
\text { at Sofia Airport; the } \\
\text { privatization of BTC; } \\
\text { development of } \\
\text { regulatory framework for } \\
\text { e-commerce; } \\
\text { development of e- } \\
\text { government }\end{array}$ & $\begin{array}{lr}\text { construction } & \text { and } \\
\text { operation of an } & \text { ansort } \\
\text { intermodal transport } \\
\text { terminal in the city Sofia; } \\
\text { active investment } \\
\text { program for the } \\
\text { construction of modern } \\
\text { infrastructure - by } \\
\text { financing private sector } \\
\text { by the state budget and } \\
\text { pre-accession, Structural } \\
\text { and Cohesion Funds; } \\
\text { recovery of the damages } \\
\text { at the rail infrastructure } \\
\text { caused by natural } \\
\text { disasters in 2005; } \\
\text { implementing of a } \\
\text { national transport } \\
\text { scheme }\end{array}$ & $\begin{array}{l}\text { reconstruction of the } \\
\text { railway line Plovdiv - } \\
\text { Svilengrad; new border } \\
\text { combined (road / rail) } \\
\text { bridge over the River } \\
\text { Dunav at Vidin - Calafat; } \\
\text { Lyulin highway; } \\
\text { technical assistance for } \\
\text { the rehabilitation of } \\
\text { railways; new airport } \\
\text { control tower at the } \\
\text { airport Sofia; building } \\
\text { some highways by OP } \\
\text { "Transport"; public- } \\
\text { private partnership; } \\
\text { transformation of the } \\
\text { airports in separate } \\
\text { business units; } \\
\text { construction of an } \\
\text { intermodal terminal in } \\
\text { Sofia }\end{array}$ \\
\hline
\end{tabular}

Source: The system of legal information of the Council of Ministers, see:

http://pris.government.bg/prin/login.aspx?ReturnUrl=\%2fprin\%2fdefault.aspx

Detailed programme of action of the Cabinet Sakskoburggotski is complemented by the following strategic documents:

- A programme for the privatization of state enterprises in 2002 (accepted at 20.11.2001), which seeks continuation of structural reforms and a speeding up of privatization as part of an overall package of decisions necessary for the implementation of sustainable economic growth and the completing of the transition to a functioning market economy. The main priorities in privatization are: privatization in the short term of other state-owned enterprises (majority stakes) from industry, trade, tourism, construction, agriculture, transport, energy and others; accelerate the process of privatization of infrastructure monopolies and enterprises in public services; privatization through public offering of packages of shares on the stock exchange, including packages of shares of companies with monopolistic position; sale of minority packages of shares and blocks of shares owned by the state as well as completion of voucher privatization;

- National Strategy for promoting the development of small and medium-sized enterprises for 2002-2006 and the work program for implementation of the National Strategy for promoting the development of small and medium-sized enterprises for the period 2002-2006 (adopted on 01.04.2002): main priority is to support small and mediumsized enterprises;

- Various short-, medium- and long-term initiatives, which present detailed measures and actions, as well as the institutions responsible for their implementation;

- Action Plan for 2002-2006, and work program for 2002 to the Communication Strategy for the Accession of the Republic of Bulgaria in the European Union (from 30.04.2002);

- Strategy for the participation of Bulgaria in the Structural Funds and the Cohesion Fund of the European Union (from 28.05.2002);

- Pre-accession Economic Programme of the Republic of Bulgaria for the period 2002-2005 (from 24.09.2002);

- National Plan for Combating Poverty and Social Exclusion 2004 (19.01.2004 onwards); 
- Pre-accession Economic Programme of the Republic of Bulgaria for the 2004-2007 (from 22.11.2004);

- National Action Plan for Employment in 2005 (from 14.02.2005 onwards);

- Annual Programme for implementing the National Strategy for Promotion of SMEs in 2005 (from 30.03.2005);

- Innovation Strategy of the Republic of Bulgaria and measures for its implementation (08.09.2004);

- Strategy to promote investments in the Republic of Bulgaria (2005 - 2010 years) (30.06.2005);

On 30.11.2005 is adopted the programme of action of the coalition government with Prime Minister Sergey Stanishev. The author assesses the difficult process of formation of the coalition and its heterogeneous character as a reason for the absence of specific economic objectives and measures in the programming document. After failing two exploratory mandates to create a government, President Georgi Parvanov awarded the third term of the third largest parliamentary group DPS. The coalition BSP-NMSS-MRF initially perceived the social liberal model, but during the mandate focuses mainly on European integration and the accession of Bulgaria to the European Union. Specific economic objectives of the 86th government are described in the relevant strategic documents:

- National long-term programme for energy efficiency by 2015 (from 04.07.2005 onwards);

- National Strategic Reference Framework 2007 - 2013 years (from 21.12.2006), which is a medium to long-term strategic document, describing the role of the Structural Funds in Bulgaria in the period 2007 - 2013. It focuses on four key priorities - improving basic infrastructure, improving the quality of human capital with a focus on employment, promote entrepreneurship, favorable business environment and good governance, support for balanced regional development;

- National Reform Programme of the Republic of Bulgaria (2008-2010) and the Action Plan for the National Reform Programme of the Republic of Bulgaria (2008-2010) (from 27.10.2008);

- Vision 2013: Export Policy of the Republic of Bulgaria from 2008 to 2013 (from 23.12.2008). The export policy of Bulgaria aims to improve the investment environment in Bulgaria, promoting investments with high added value, improve the investment marketing services for investors and implementation of proactive export policy. The document regulates the development of industrial zones with infrastructure support provided by the state. "Vision 2013" provides for the development of a comprehensive marketing program in targeted sectors/ regions and the maintenance of an integrated information system;

- An updated Employment Strategy of the Republic of Bulgaria 2008 - 2015, from (30.04.2008);

- National Action Plan for Employment in 2009 (from 15.01.2009);

- Vision for a new development policy of Bulgarian Railways (2008 - 2013) (from 02.02.2009). This is a vision for a purposeful policy to reduce the intensity on the roads and improve traffic safety and to protect the environment from the adverse impacts of road transport. At the core of this policy is the revitalization of the railways, increasing their market share at the expense of redistribution of shipments by road and rail;

- National Strategy for Sustainable Tourism Development in the Republic of Bulgaria 2009-2013, (02.04.2009). The National Strategy systematize vision, strategic goals, priorities, specific goals, objectives, activities and projects whose implementation will lead to the establishment of sustainable development schemes and management of tourism activities. The strategy is a platform for coordinated joint action of all tourism stakeholders to absorb the tourist potential of the country.

The programme of action of 87 th Government is a detailed document that presents the political commitments of party GERB which are revealed in the election programme in 2009. The following strategic documents develop the economic priorities of The first cabinet Borisov:

- Annual programme for the participation of Bulgaria in the process of decision-making of the European Union (2011) (from 17.01.2011);

- Plan for action for 2010 with the measures resulting from the membership of the Republic of Bulgaria in the European Union (from 14.01.2010);

- National Plan for Employment in 2011 (from 29.12.2010);

- National Reform Programme (2011-2015 years) (April 2011);

- National Plan for Employment in 2012 (from 29.12.2011): The National Plan for Employment 2012 supports the economic 
and social recovery and stabilization of the labor market. It is an instrument for the realization of the goals and commitments of the country in terms of the EU Strategy 2020 and the measures included in the National Reform Programme 2011 - 2015;

- Second National Action Plan on energy efficiency (from 16.11.2011);

- National Action Plan for energy from renewable sources (from 01.09.2013). The plan is based on an integrated approach to public and social life, the development of economic sectors, the protection and preservation of the environment, the protection of the human life and health. The aim is to provide a transition towards a low carbon economy based on modern technologies and greater use of renewable energy sources;

- National plan for employment in 2013 (from 04.2.2013).

\section{CLOSING WORDS}

By diachronic-comparative analysis of the key economic priorities at the government programmes of the Bulgarian governments in period 2001 - 2013, it can be concluded that there is no strict ideological and political approach to identify the main economic goals.
Most of the priorities in the economic sphere are result of common principles and nonpartisan initiatives for stable economic growth and prosperity of private business.

\section{REFERENCES}

1. Peck, S. and Gibson, R. Pushing the Revolution. In Alternatives Journal, Vol. 26, No. 1, 2000

2. Muldoon, P. and Nadarajah, R. A sober second look. In Voluntary initiatives: The new politics of corporate greening, ed. R. Gibson, pp. 51-65. Peterborough, ON: Broadview, 1999

3. Bell, D. The Role of Government in Advancing Corporate Sustainability, York Centre for Applied Sustainability, http://www.irisyorku.ca/wpcontent/uploads/ 2007/05/file_the_role_of_government_in_a dvancing_corporate_sustainability.pdf

4. http://www.iriasl.org/files/government_pro gram1.pdf

5. http://pris.government.bg/prin/document_vi ew.aspx?DocumentID=aQUSwj48WUoI1F ih39YO9Q

6. http://pris.government.bg/prin/document_vi ew.aspx?DocumentID=U2vHja8WCCYurfj dFtLxkw 